\title{
Interview with Mr. Jeffrey Alderman, CE0, ACBSP
}

SDMIMD is proud in receving the accreditation from the Accreditation Council for Business Schools and Programm (ACBSP), US, for our flagship management program PGDM. Mr. Jeffrey Alderman, President/ $C E O, A C B S P$, recently, has visited India. Prior to joining ACBSP, Mr. Alderman served as Vice President of the Kansas City, Kansas Chamber of Commerce overseeing business development for the Chamber by working with small to large scale businesses on consulting, branding, and marketing initiatives. A sampling of member companies includes General Motors, Kansas Speedway, Sporting Kansas City, and The University of Kansas Medical Center. SDMIMD had the honor to have Mr. Alderman in the campus, where he addressed the students and interacted with the faculty members. The Dimension Team (Student Magazine) from SDMIMD has an opportunity to interview Mr. Alderman on various aspects. The discussion has been summarized below.

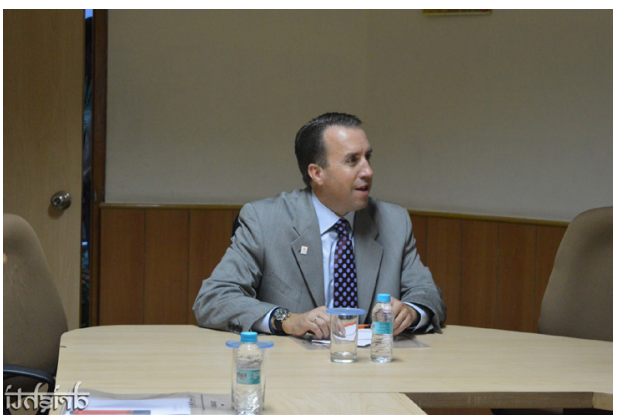

Dimension: What is the motivation behind establishing ACBSP and what parameters does ACBSP considers to accredit an institute?

Mr. Alderman: ACBSP, The Accreditation Council for Business Schools and Programs was founded in 1988. ACBSP was formed based on the opportunity to prove that Business school come to share best practices. 160 schools, which were now accredited, were invited to Kansas City, mainly because Kansas City is the geographic centre for the continental USA. What they talked about was the opportunity to learn from each other through the sharing of what we call "Best Practices". It means one school may be doing something, that is the best, and, another school may be doing something else, that is the best. We can come together and learn from each other to adopt each others' best practices. Prior to that, AACSB and EFMD were the only accreditors in the world. Some of our schools decided to create our own accreditation body. This way, ACBSP was born. ACBSP has gone from zero members to over one thousand two hundred members in twenty nine years. So, it is really learning from each other. ACBSP started with Baldrige standards in 1988. Since then, we have been applying Balridge standards to our accreditation process.

Dimension: Sir, you mentioned about the best practices, shared by the various schools. Could you kindly share what are some activities ACBSP does to accomplish the sharing process?

Mr. Alderman: Sure. As a scholarly organization, we try to create scholarly activities in addition to the accreditation process and practices. All the Faculty and administrators are involved in what is called as scholarly activities, and that involves the opportunity to present to your peers presenting papers. For example, when we will have the Region 10 Conference in Mysore, we are going to have professors, all over South-Asia presenting their work. So thats part of scholarly activity. We also provide opportunities to publish the scholastic work. We have a scholarly journal called "The Transnational Journal of Business (TJB)". The TJB allows faculty to present their findings in a research study and then their findings will be published in the journal. The journal is housed in ACBSP's Washington DC Library Congress for public. This allows a faculty member's scholarly work published and recognized by Library of Congress. Then, we have many other activities, that connect faculty members to rest of the world. We have volunteer committees, governance committee, symposia, conferences, which allow people to connect and learn from each other. A famous American phrase is "Is not what you know, It's who you know", and that is true in scholarly activities, as well. So, meeting other people, learning from them, are some of other things that ACBSP does. Those are just ahead of what we do 
for our faculty and for administrators. There are activities every month that people can be involved in, either electronically, or, in person.

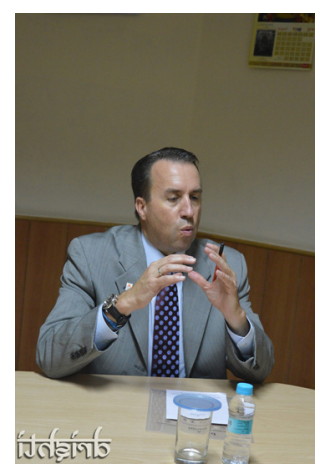

Dimension: When an Institute gets accredited, what are the advantages it gets in terms of collaboration with other Institutes? For example, faculty collaboration of one Institute with other Institutes is an advantage. What are the other similar advantages?

Mr. Alderman: First of all, students should leverage the fact with employers or with schools that they want to go onto further their education that, they went to an accredited school. So it is up to you and your fellow students to say "Hey! I graduated from a globally recognized accredited school". This is the first thing that you should do. Being a student of Marketing myself, among various the other subjects that I study, I can tell that, you need to market yourself. So please market yourself. As far as the employers are concerned, you should tell them that you went to an accredited school. How would you be looking and leveraging that other school? That's where it becomes tricky because each school has their own admission standard and that they have set up by their world region and we can't control that. If you are going to another ACBSP school, certainly they see on your application that you went to an accredited school. Then, that can be an aspect for consideration of your application. So that would help you. But there are lot of variables, which influence the final decision, such as, your grades, the courses you took. However, it will help you. And when folks sit around a table and then they look at whom they are going to admit and whom they are not going to admit. Looking at that, being from a globally accredited school may be the last point that helps us again.
Dimension: What are the benefits an Institute gets, in terms of visibility, if it is accredited by ACBSP?

Mr. Alderman: That's a great question. Certainly ACBSP is in the business of branding itself and branding the schools that it works with. I was recently in New York City at a meeting at the United Nations, building network, and, working with accreditors from all over the world to make ourselves known, so that it benefits the schools that we work with. For Instance, ACBSP works with countries all over the world. They ask about how can we create higher education standards. I say, here are the standards ACBSP employs; why don't you let us help you raise your standard of higher education. So we work with countries like Peru, Mongolia, countries in Africa, to help them raise standards of higher education. That helps brand ACBSP. It's my job and job of our schools to leverage this, so that, everybody knows that they are accredited. So, we work very hard on what we do, work with governments firstly with electronic means, and we work with our web presence and all of those things. I work with many people with businesses. Ultimately we want businesses to know when they look at an ACBSP graduate is that someone, that doesn't have to be re-trained. So we are trying to work with bigger companies like Walmart, Microsoft and those hiring companies, so that, they know the differences. Apart from that, there is the student's responsibility. Because when you do get hired by those companies, you need to excel and you have to perform.

Dimension: Can you tell us the activities ACBSP does for students?

Mr. Alderman: We have activities for both students and faculty. The students have to present their work in quality and should work with the faculty. That is a great thing. We are creating opportunities for faculty are working close to the students. The other thing is the Muscle memory. All the faculty have to adhere to the process of accreditation their teaching and what they do to maintain the standards. They talk about how to improve the business prophecies, curriculum and academic processes. So hopefully, they do it every day, living it every day. They develop routines, that make 
them better faculty members and make them work open to change. Stakeholder feedback from students allows them to do that every day, so that they need have to think about it. We often refer to the glacial period of change in academia. Glacial means a piece of ice flows very slowly down the ocean. That means we don't like change. But world is now proactive. Companies change every day, and, so should academia. We are part of that and we help the faculty developing habits to benefit you as students, through the accreditation process.

Dimension: Lot of global institutions have been accredited. Can you tell us how the Indian institutes are different from these schools?

Mr. Alderman: One thing I don't want to do is, to compare schools. I do think it is the approach that the Indian schools have, in terms of commitment by your families, by you as students, and your overall creativity and attention to details is quite evident. And this doesn't exist in Europe and it doesn't exist in the United States. The paradigms of success of wanting to be successful as compared to other B-schools, is quite evident in India. It is exciting to see such a thing, I am quite successful, my family is successful, my B-school is successful, and, it is a wonderful thing. It is lot of competitiveness in the world particularly in United States and people want to be selfish to be successful for themselves. But what I think Indian schools have, in terms of learning techniques, has made this community of long way allowing you to success not only the personal life but also academic life. And I think the focus on teaching excellence is something that allows Indian schools to become unique. There are several types of schools that exist in the world. Some of them are research oriented, where they send a professor to do a research paper for two years to study something and they come out with a white paper. But they never taught a class during those two years. Whereas your professor in an Indian B-school, is in a class room every day, teaching students and learning. I think that is a wonderful way to connect with the students and remain current and teaching techniques, which benefits the students. ACBSP works with schools, that have a mile in teaching excellence and certainly all of the B-schools in India, that we work, have teaching excellence.
Dimension: What are the future parameters that you want to consider to enhance the learning and also your future plans in terms of collaboration?

Mr. Alderman: I think the collaboration of accredited institutions is using technology to connect you. We talked about how difficult it is to see each other in person. So, we try to create a program that would allow schools, faculty and students to create a profile. So, you create a profile and a student in Europe creates a profile and then, we match you together to reconnect you. The other thing we do is, to look at what best the student has, what best the faculty has, in curriculum development that is happening in United States, and, is already happening in India. Businesses should be involved in curriculum development. Because, previously B-schools have decided what they would teach their students, and, they would graduate and get jobs. Remember what I talked about perception of businesses about the students of not being prepared. Microsoft is involved in developing curriculum. I think it is wonderful thing because you automatically not only going to school to increase your knowledge but you are also automatically increasing your employability because you are able to provide your family, as a part of accreditation. This is a positive change that I see involving the businesses in curriculum development. KPMG has a program with several B-schools with an MBA programme in United States. You graduate with KPMG MBA with certain grade, and then, you will have a job. B-schools all over the world are closing because they don't provide employability in their students. Accreditation is part of that it helps to minimize the gap in the perception and reality what the students are prepared for.

Dimension: What are the unique things that you saw in SDMIMD as a B-school?

Mr. Alderman: SDMIMD came to us because they wanted to improve. Accreditation is not compulsory. We introduce schools to the idea of conception of what the accreditation can do for the school, for the faculty and for the students. So it is something that this message resonated with the faculty here and the Director, Dr. Parasuraman, and they decided to prove the program to be one of the globally recognized. They wanted to 
become a better school, with better students, with better faculty. That's the first step for a school, willing to be accredited. Now, we have a school, that applies for membership. We have standards for membership we will view. Not everyone, who comes to ACBSP with a cheque book, gets accepted for accreditation. We have standard of membership that we have at ACBSP. Certainly, SDMIMD reached those standards and they were accepted as member school. After you become a member, is to apply for candidacy. When you apply for candidacy, you create a self-evaluation to ask question about yourself, with respect to self-evaluation. We will view that and we determine through the answers to that questionnaire, whether you are ready for candidacy or not. Some schools are ready and others are not. Certainly this school was ready. It involves lot of hard work. I don't like to use the word checking up, but you need to have to exceed the standards. We are not in a business of accepting schools, that we don't believe in them being accredited. 